Prof. Dr. Nijaz Skender, vanredni profesor

\title{
Analiza razlika motoričkih sposobnosti kod učenika III i \\ IV razreda osnovne škole pod utjecajem posebnog kineziološkog programa
}

\section{Sažetak}

Utvrđivanje kvantitativnih razlika motoričkih sposobnosti, provedene su na uzorku od 206 ispitanika učenika 3. $i$ 4. razreda osnovne škole. Svi ispitanici su učenici OŠ "25 novembar" iz Velike Kladuše. U istraživanju korišten je skup od 16 varijabli motoričkih sposobnosti.

Osnovni cilj ovog istraživanja je bio da se utvrde transformacije motoričkih sposobnosti učenika, metodom paralelne analize rezultata uzoraka eksperimentalne grupe $u$ odnosu na kontrolnu grupu, da se utvrdi koji od ponuđenih modela nastavnih programa daje efikasnije rezultate transformacija motoričih sposobnosti.

Analizom parcijalnih kvantitativnih promjena testiranih (Ttestom) motoričkih sposobnosti eksperimentalne $i$ kontrolne grupe $u$ inicijalnom mjerenju konstatirano je da nisu dobijene značajne parcijalne razlike kod većeg broja motoričkih varijabli između eksperimentalne i kontrolne grupe. Na osnovu čega je zaključeno da te dvije grupe ispitanika pripadaju istoj populaciji.

$\mathrm{Na}$ osnovu dobijenih parametara testiranih (T-testom) motoričkih sposobnosti eksperimentalne i kontrolne grupe u finalnom mjerenju konstatirano je da su dobijene značajne parcijalne razlike $u$ svim varijablama motoričkih sposobnosti (izuzev jedne) između eksperimentalne i kontrolne grupe.

$\mathrm{Na}$ osnovu rezultata $u$ diskriminativnoj analizi, globalnih razlika primijenjenih motoričkih varijabli između eksperimentalne $i$ kontrolne grupe nakon završetka dva paralelna programa u trajanju od 7 mjeseci, utvrđeno je da je i između ove dvije grupe došlo do značajnih globalnih razlika u testovima motoričkih sposobnosti pod dejstvom efekata dva različita programa. Program eksperimentalne 
grupe koji je bio obimniji utjecao je na pozitivne transformacije kod gotovo svih motoričkih sposobnosti, a naročito koordinaciju, eksplozivnu snagu, repetitivnu snagu ifleksibilnost.

Ključne riječi: motoričke sposobnosti, razlike, eksperimentalna grupa, kontrolna grupa, diskriminativna analiza.

\section{Uvod}

Programirane nastavne aktivnosti pored cilja i određenog programa podrazumijevaju i postojanje kvalitetne povratne sprege koja je u funkciji pravovremenog poduzimanja mjera za adaptaciju procesa pedagoške aktivnosti individualiziranim potrebama učenika. Stoga su bitne promjene u ponašanju pedagoga, u procesu nastave tjelesnog i zdravstvenog odgoja, koje su sukladne kibernetskom i humanističkom poimanju nastave. Ponašanje nastavnika treba da u okviru grupne nastave obezbijedi individualizirane utjecaje ne učenike i kvalitetnu povratnu informaciju. Pažljivom provjerom tranzitnih stanja treba da utvrdi napredak ili stagnaciju, te na osnovu tih stanja mijenjati operatore.

Da bismo pomoću tjelesnog vježbanja djelovali sigurno i efikasno na cjelokupni antropološki status učenika, na njihov tjelesni razvoj, na razvoj njihovih osobina i sposobnosti, na fond motoričkih znanja, raznih motoričkih dostignuća te odgojne efekte rada, nužno je utvrditi ne samo aktualno stanje antropološkog statusa učenika, odrediti smjernice njihove transformacije, nego istodobno osigurati i dobivanje povratnih informacija o rezultatima rada i napretku učenika. Dakle, sve to, kao i činjenica da kineziološka nauka raspolaže svakim danom sve većom količinom informacija o vrijednostima (pojedinih) kinezioloških aktivnosti pomoću kojih se može utjecati na transformaciju antropološkog statusa učenika, dovodi nas do zaključka da su planiranje, programiranje, provođenje i kontrola procesa tjelesnog vježbanja osnovni uvjeti za zadovoljavanje autentičnih potreba učenika.

Da bi se brojni i vrlo složeni zadaci tjelesnog i zdravstvenog odgoja uspješno realizirali potrebno je unaprijed predvidjeti što će se raditi u jednom dužem vremenskom razdoblju, a to znači planirati. Od nastavnika se dakle očekuje da svojim planom, odnosno programom 
unaprijed predvidi kako će realizirati odgojno-obrazovni rad sa svojim učenicima u toku jedne školske godine.

Utjecaji posebnih programa na motoričke sposobnosti bili su predmet nekih dosadašnjih naučnih istraživanja: Babin, J., R. Katić, L. Vlahović (1999); Bavčević,T., J. Babin, I. Prskalo (2006); Blažević, S. (1997); Hadžikadunić M. (2000); Luka M., I. Jukić, S. Šimek (2006); Malina, R.M. (1984); Mraković, M., V. Findak, D. Metikoš, B. Neljak (1996); Stanković A. (2002); Skender N. (2004); Tabaković, M., S. Turković, N. Skender (2005).

U većini dosadašnjih istraživanja utjecaja posebnih programa na motoričke sposobnosti, utvrđene su značajne parcijalne i globalne kvantitativne razlike (promjene) u testovima motoričkih sposobnosti pod utjecajem određenih programa.

\section{Cilj istraživanja}

Osnovni cilj ovog istraživanja baziran je na utvrđivanju kvantitavnih parcijalnih i globalnih razlika (promjena) primijenjenih bazičnih motoričkih sposobnosti između eksperimentalne i kontrolne grupe učenika 3. i 4. razreda osnovne škole, poslije realizacije dva modela programa.

Drugi cilj ovog istraživanja je da se utvrdi koji od dva ponuđena modela nastavnih programa daje efikasnije rezultate transformacija $\mathrm{u}$ motoričkom prostoru. Model koji je realizovala eksperimentalna grupa izvodio se po posebnom programu $(3 \times 1$ sat sedmično), ili model koji je realizovala kontrolna grupa koji se izvodio po postojećem nastavnom planu i programu (2x1 sat sedmično).

\section{Metode rada}

\section{Uzorak ispitanika}

Uzorak ispitanika u ovom istraživanju predstavlja 206 učenika 3. i 4. razreda OS̆ "25 novembar" iz Velike Kladuše. Uzorak se može smatrati neselekcioniranim jer učenici nisu uključeni u sistematski sportski trenažni proces i sportske klubove. Učenici su metodom 
slučajnog uzorka podijeljeni $u$ dvije podjednake grupe eksperimentalnu i kontrolnu.

\section{Uzorak varijabli motoričkih sposobnosti}

Uzorak varijabli za procjenu bazičnih motoričkih sposobnosti u ovom istraživanju sačinjava skupina od 16 mjernih testova. testovi:

Za procjenu utvrđivanja koordinacije primijenjeni su slijedeći

1. pretklon zasuk dodir (MKOPZD)

2. skok udalj natraške (MKOSDN)

3. koraci u stranu (MKOKS)

4. čunasto trčanje $10 \times 5$ metara (MKOT10X5)

Za procjenu utvrđivanja eksplozivne snage primijenjeni su slijedeći testovi:

1. skok udalj s mjesta (MESSDM)

2. skok uvis s mjesta (MESSAR)

3. trčanje $20 \mathrm{~m} \mathrm{~V} / \mathrm{S}$ (MEST20M)

Za procjenu utvrđivanja repetitivne snage primijenjeni su slijedeći testovi:

1. podizanje trupa trbuh $30 \mathrm{sec}$ (MRSPTT)

2. duboki čučnjevi $40 \mathrm{sec}$ (MRSDČ)

3. izdržaj u zgibu (MRSIZZ)

Za procjenu utvrđivanja brzine primijenjeni su slijedeći testovi:

1. taping rukom (MBTR)

2. taping nogom (MBTN)

3. taping nogom od zid (MBTNZ)

Za procjenu utvrđivanja fleksibilnosti primijenjeni su slijedeći testovi:

1. pretklon na klupici sjedeći (MFDP)

2. iskret palicom (MFIP)

3. pretklon iz sjeda raznožno ugao 45\% (MFPSR) 


\section{Metode obrade podataka}

Da bi se na univarijantnom nivou uspješno utvrdile parcijalne kvantitativne razlike za svaku primijenjenu varijablu, testirane su razlike T-testom za nezavisne uzorke, koje su nastale kroz dvije vremenske tačke (inicijalno i finalno mjerenje), kao i razlike između eksperimentalne i kontrolne grupe $u$ inicijalnom $i$ finalnom mjerenju.

Za utvrđivanje globalnih kvantitativnih razlika između eksperimentalne i kontrolne grupe, koje su nastale kroz dvije vremenske tačke (inicijalno i finalno mjerenje), primijenjena je kanonička diskriminativna analiza.

\section{Rezultati i diskusija}

U ovom istraživanju prije realiziranja dva modela programa, izvršena je analiza parcijalnih kvantitatativnih razlika motoričkih sposobnosti eksperimentalne i kontrolne grupe u inicijalnom mjerenju. Najjednostavniji slučaj razlikovanja ispitanika je kada se analiziraju razlike između aritmetičkih sredina dvije grupe ispitanika na osnovu jedne manifestne ili latentne varijable. Test za testiranje značajnosti parcijalnih razlika između aritmetičkih sredina dvije grupe ispitanika u jednoj varijabli naziva se T-test. Na osnovu T-testa utvrđuje se, u stvari koliko je puta razlika dviju aritmetičkih sredina veća od svoje pogreške. Smatra se da je ta razlika statistički značajna ako je najmanje dva puta veća od svoje pogreške $(\mathrm{Sig}<.05)$.

$\mathrm{U}$ tabeli 1 prezentirani su podaci aritmetičkih sredina, standardnih devijacija i T-testa eksperimentalne i kontrolne grupe učenika u inicijalnom mjerenju primijenjenih motoričkih sposobnosti.

Pregledom vrijednosti aritmetičkih sredina (Mean) eksperimentalne i kontrolne grupe, može se uočiti da su te vrijednosti prilično izjednačene kod svih primijenjenih motoričkih varijabli. Već na ovom nivou analize može se dati konstatacija, da između eksperimentalne i kontrolne grupe u inicijalnom mjerenju, ne postoje značajne razlike $u$ vrijednosti rezultata primijenjenih motoričkih sposobnosti.

Daljnom analizom značajnosti razlika testiranih T-testom, može se takođe uočiti, da gotovo sve primijenjene varijable 
motoričkih sposobnosti $\mathrm{u}$ eksperimentalnoj i kontrolnoj grupi $\mathrm{u}$ inicijalnom mjerenju nisu postigle koeficijent statističke značajnosti $($ Sig < .05). Mogu se uočiti vrijednosti T-testa koje nam pokazuju da se ispitanici u inicijalnom mjerenju ne razlikuju statistički značajno, jer je vrijednost T-testa manja u svim varijablama motoričkog prostora od svoje pogreške.

$\mathrm{Na}$ osnovu prezentiranih rezultatata može se zaključiti da su parcijalne razlike primijenjenih motoričkih sposobnosti eksperimentalne i kontrolne grupe $\mathrm{u}$ inicijalnom mjerenju statistički beznačajne, odnosno da te dvije grupe ispitanika pripadaju istoj populaciji u odnosu na analizirane varijable, te da je pri tome moguća greška tipa II i to od $5 \%$, izuzev u dvije varijable (MKOPZD i MBTR), kod kojih postoji statistički značajna razlika na nivou (Sig < $.05)$.

Tabela 1

Nakon što je u inicijalnom mjerenju utvrđeno da su parcijalne razlike primijenjenih motoričkih sposobnosti eksperimentalne i kontrolne grupe statistički beznačajne, odnosno da te dvije grupe ispitanika pripadaju istoj populaciji, što je bio preduslov za dalji nastavak istraživanja, došlo je do realizacije dva modela programa $u$ trajanju od 7 mjeseci.

Osnovne karakteristike ta dva modela programa su bile:

1. Model koji je realizovala eksperimentalna grupa izvodio se po posebnom programu (3x1 sat sedmično) uz raznovrsne sadržaje iz atletike, sportske gimnastike i sportskih igara. Sa eksperimentalnom grupom radili su učitelji razredne nastave, ali uz nadzor profesora, odnosno nastavnika tjelesnog i zdravstvenog odgoja.

2. Model koji je realizovala kontrolna grupa izvodio se po postojećem nastavnom planu i programu (2x1 sat sedmično). Sa kontrolnom grupom radili su samo učitelji razredne nastave.

Nakon realizacije dva navedena modela programa koji su trajali 7 mjeseci pristupilo se finalnom mjerenju i prvo analizi 
parcijalnih kvantitatativnih razlika (promjena) motoričkih sposobnosti eksperimentalne $\mathrm{i}$ kontrolne grupe $\mathrm{u}$ finalnom mjerenju T-test.

U tabeli 2 prezentirani su podaci aritmetičkih sredina, standardnih devijacija i T-testa eksperimentalne i kontrolne grupe učenika u finalnom mjerenju primijenjenih motoričkih sposobnosti.

Pregledom vrijednosti aritmetičkih sredina (Mean) eksperimentalne i kontrolne grupe, može se uočiti da postoje razlike rezultata kod gotovo svih primijenjenih varijabli motoričkih sposobnosti, te da te razlike idu u korist eksperimentalne grupe. Može se konstatovati da između eksperimentalne $\mathrm{i}$ kontrolne grupe $\mathrm{u}$ finalnom mjerenju, postoje značajne razlike $\mathrm{u}$ vrijednosti rezultata primijenjenih motoričkih varijabli.

Analizom značajnosti razlika testiranih T-testom, može se takođe uočiti, da su gotovo sve primijenjene varijable motoričkih sposobnosti u eksperimentalnoj i kontrolnoj grupi u finalnom mjerenju postigle koeficijent statističke značajnosti (Sig <.05). Mogu se uočiti vrijednosti T-testa koje nam pokazuju da se ispitanici u finalnom mjerenju razlikuju statistički značajno, rezultati T-testa pokazuju, da su razlike u svim varijablama izuzev jedne (MKOSDN) statistički značajne na nivou $($ Sig $<.05)$.

$\mathrm{Na}$ osnovu toga može se zaključiti da su parcijalne razlike primijenjenih motoričkih sposobnosti eksperimentalne i kontrolne grupe u finalnom mjerenju statistički značajne, odnosno da je nakon realizacije dva modela programa došlo do značajnih razlika u analiziranim bazičnim motoričkim sposobnostima kod te dvije grupe ispitanika, a u korist eksperimentalne grupe.

Tabela 2

Poslije finalnog mjerenja i analize parcijalnih kvantitatativnih razlika, pristupilo se analizi globalnih kvantitatativnih razlika (promjena) motoričkih sposobnosti eksperimentalne i kontrolne grupe. Da bi se utvrdile globalne kvantitativne razlike rezultata primijenjenih motoričkih sposobnosti između eksperimentalne i kontrolne grupe pod 
utjecajem dva modela programa koji su se sprovodili 7 mjeseci, primijenjena je kanonička diskriminativna analiza.

Kanonička diskriminativna analiza je metoda koja vodi računa o kvantitativnim veličinama pojedinih varijabli i o njihovim međusobnim odnosima. Diskriminativni model predstavlja poseban tip faktorske analize u kojoj se izoluju ortogonalni vektori u prostoru manifestnih varijabli, koji su postavljeni tako da najbolje razdvajaju grupe ispitanika u prostoru varijabli (Rađo i Wolf 2002). Kriterij za diskriminativnu jačinu primijenjenih varijabli bio je tzv. (Wilksova Lambda). Određivanje statističke značajnosti svake diskriminativne varijable vršeno je na osnovu (Bartletovog Hi-kvadrat testa). Za interpretaciju korištene su značajne diskriminativne varijable i one objašnjavaju određeni procenat varijabiliteta.

U tabeli 3 (Boxovim M-testom) testirana je sličnost matrica kovarijansi između dva subuzorka (Rađo i Wolf 2002), tj. između eksperimentalne i kontrolne grupe ispitanika. Može se vidjeti da je razlika matrica kovarijansi statistički značajna $(S i g=.00)$, te dozvoljava pristup daljnoj proceduri kanoničke diskriminativne analize.

Tabela 3

U (tabeli 4) prikazani su rezultati kanoničke diskriminativne analize $\mathrm{s}$ pokazateljima značajnosti razlika eksperimentalne i kontrolne grupe u primijenjenim motoričkim sposobnostima. Dobijena je jedna statistički značajna kanonička diskriminativna funkcija, koja ima statistički značajnu vrijednost (Canonical Correlation $=.59$ ).

Tabela 4

$\mathrm{Na}$ osnovu rezultata (u tabeli 5) može se uočiti da najveće korelacije sa diskriminativnom funkcijom, odnosno sa varijablom koja maksimalno razlikuje vrijednosti rezultata motoričkih sposobnosti dva subuzorka (eksperimentalne i kontrolne grupe), imaju slijedeće motoričke varijable: dvije manifestne varijable za procjenu 
eksplozivne snage (MEST20M i MESSAR), dvije manifestne varijable za procjenu repetitivne snage (MRSPTT i MRSIZZ), tri manifestne varijable za procjenu koordinacije (MKOPZD, MKOKS i MKOT10X5) i dvije manifestne varijable za procjenu fleksibilnosti (MFDP i MFIP). Znači u ovim varijablama najveće su razlike (promjene) vrijednosti rezultata primijenjenih motoričkih sposobnosti između eksperimentalne i kontrolne grupe ispitanika, nakon realizacije dva modela programa.

Daljnom analizom strukture diskriminativne funkcije, može se vidjeti da gotovo sve varijable statistički značajno diskriminiraju te dvije grupe ispitanika, te da su vrijednosti korelacija sa diskriminativnom funkcijom ujednačene. Test brzine (MBTN) ima također značajnu korelaciju sa diskriminativnom funkcijom, ali nešto nižu nego prethodno navedene varijable. Vjerovatno se to može objasniti stepenom urođenosti brzine, koja je u većini istraživanja kod različitih autora utvrđena između 80 i $90 \%$. Drugi razlog je vjerovatno u odabiru testova. Naime, najbolji testovi brzine su testovi trčanja letećim startom, međutim zbog ograničenosti prostornih uvjeta nije mogao biti primijenjen ovaj test, ali svakako u narednim istraživanjima treba uzeti u obzir i ovu činjenicu.

Jedina varijabla koja nema nikakvu statistički značajnu vrijednost korelacije sa diskriminativnom funkcijom je manifestna varijabla za procjenu koordinacije (MKOSDN). To se vjerovatno može objasniti specifičnostima samog testa skok udalj natraške (MKOSDN), koji spada u testove reorganizacije stereotipa gibanja, koja je definirana kao sposobnost savladavanja inertnog djelovanja postojećih stereotipa gibanja. Vjerovatno ni jedan od realizovana dva modela programa nije imao dovoljno vježbi i kretanja takvog tipa, tako da navedena varijabla nema ni statistički značajnu vrijednost korelacije sa diskriminativnom funkcijom.

\section{Tabela 5}

Uzimajući u obzir prethodne konstatacije prilikom analize Ttesta, i kanoničke diskriminativne analize, te na osnovu dobijenih parametara može se konstatirati da su dobijene značajne razlike (promjene) vrijednosti rezultata motoričkih sposobnosti između 
učenika eksperimentalne i kontrolne grupe, nakon realizacije dva modela programa. Takođe se može konstatirati da te razlike (promjene) idu u korist učenika eksperimentalne grupe, odnosno oni posjeduju znatno veći nivo primijenjenih bazičnih motoričkih sposobnosti u odnosu na učenike kontrolne grupe.

Razlozi za ovako utvrđene razlike (promjene) vrijednosti kod rezultata primijenjenih bazičnih motoričkih sposobnosti između eksperimentalne i kontrolne grupe ispitanika nakon realizacije dva modela programa (posebnog i postojećeg), najvjerovatnije su slijedeći:

- Specifičnosti dva modela programa u trajanju od 7 mjeseci koji su realizirale eksperimentalna i kontrolna grupa, sigurno su doprinijele tim razlikama (promjenama), kod rezultata primijenjenih bazičnih motoričkih sposobnosti. Eksperimentalna grupa je radila po posebnom programu $(3 \mathrm{x} 1$ sat sedmično) uz raznovrsne sadržaje iz atletike, sportske gimnastike i sportskih igara. S eksperimentalnom grupom radili su učitelji razredne nastave, ali uz nadzor profesora, odnosno nastavnika tjelesnog i zdravstvenog odgoja. Kontrolna grupa je radila po postojećem nastavnom planu i programu (2x1 sat sedmično). S kontrolnom grupom radili su samo učitelji razredne nastave.

- Veći broj sati (3x1 sat sedmično) tjelesnog i zdravstvenog odgoja kod realizacije posebnog programa sigurno je izazvao veći broj pozitivnih transformacija i veći nivo motoričkih sposobnosti kod učenika eksperimentalne grupe, u odnosu na broj pozitivnih transformacija i nivo motoričkih sposobnosti kod učenika kontrolne grupe koji su realizovali postojeći program i imali (2x1 sat sedmično) tjelesnog i zdravstvenog odgoja.

- Posebni program koji je realizirala eksperimentalna grupa imao je znatno više programskih sadržaja iz atletike, sportske gimnastike i sportskih igara u odnosu na sadržaje postojećeg programa koji je realizirala kontrolna grupa. Više programskih sadržaja atletike, sportske gimnastike i sportskih igara proizveo je veći nivo pozitivnih transformacija i time podigao nivo motoričkih sposobnosti eksperimentalne grupe ispitanika. Atletika gdje dominiraju vježbe tipa trčanja, vježbe tipa sprinterskih disciplina iz raznih položaja i vježbe tipa 
podizanja trupa kako statičkih tako i dinamičkih, najvjerovatnije su najviše doprinijele razvoju eksplozivne snage, repetitivne snage i brzine. Sportska gimnastika kod koje dominiraju vježbe tipa okretnosti i spretnosti tj. vježbe kod kojih preovladavaju kompleksne strukture kretanja i vježbe tipa fleksibilnosti, najvjerovatnije su najviše doprinijele razvoju koordinacije i fleksibilnosti. Sportske igre kod kojih dominiraju vježbe tipa okretnosti, spretnosti, agilnosti, snage i brzine, najvjerovatnije su doprinijele razvoju koordinacije, eksplozivne snage, repetitivne snage $\mathrm{i}$ brzine.

- Naravno, kao razlog za ovako utvrđene razlike (promjene) rezultata motoričkih sposobnosti između eksperimentalne i kontrolne grupe ispitanika, ne može se izostaviti i činjenica da su sa eksperimentalnom grupom radili učitelji razredne nastave, ali uz nadzor profesora odnosno nastavnika tjelesnog $\mathrm{i}$ zdravstvenog odgoja. Nadzorom profesora ili nastavnika nastava tjelesnog i zdravstvenog odgoja sa eksperimentalnom grupom, sigurno je realizirana efikasnije i stručnije, u odnosu na nastavu koja je realizirana s kontrolnom grupom, s kojom su radili samo učitelji razredne nastave.

- Moramo imati u vidu i faktor permanentnog rasta i razvoja motoričkih sposobnosti kod učenika ovog uzrasta, ali je vjerojatno da su kvantitativne razlike (promjene) $\mathrm{u}$ motoričkom prostoru više posljedica značajnog povećanja kretanja cikličnog i acikličnog tipa, te povećanja nivoa polistrukturalnih i strukturalnih kretanja, koja su bila značajnije zastupljena u programskim sadržajima eksperimentalne grupe.

- Trebamo uzeti u obzir i promjene koje su došle u obrazovnom smislu kada su u pitanju učenja novih pokreta. Iskustvo koje su ispitanici stekli u periodu od prvog do drugog mjerenja, sigurno je više na strani eksperimentalne grupe u odnosu na kontrolnu grupu, radi već prethodno svih navedenih konstatacija. Eksperimentalna grupa je u tom periodu od prvog do drugog mjerenja bolje upoznala složenost i strukturu pokreta - aktivnosti koje su obuhvaćene primijenjenim setom mjernih instrumenata. 


\section{Zaključak}

Utvrđivanje kvantitavnih parcijalnih i globalnih razlika (promjena) primijenjenih bazičnih motoričkih sposobnosti između eksperimentalne i kontrolne grupe učenika 3. i 4. razreda osnovne škole, poslije realizacije dva modela programa (posebnog i postojećeg), koji su se realizirali u vremenskom periodu od 7 mjeseci, bio je osnovni cilj ovog istraživanja. To je inače jedno od ključnih pitanja u nastavi tjelesnog i zdravstvenog odgoja, kolike i kakve su promjene nastale u motoričkom prostoru nakon izvjesnog perioda pod utjecajem određenih tretmana, to je pitanje je koje zanima sve kineziologe.

$\mathrm{Na}$ osnovu rezultata parcijalnih i globalnih kvantitativnih razlika (T-testa i kanoničke diskriminativne analize) između eksperimentalne i kontrolne grupe nakon završetka dva paralelna programa u trajanju od 7 mjeseci, utvrđeno je da je između ove dvije grupe došlo do značajnih razlika (promjena) u testovima primijenjenih motoričkih sposobnosti pod dejstvom efekata dva različita programa. Takođe je utvrđeno da te razlike idu u korist učenika eksperimentalne grupe, odnosno oni posjeduju znatno veći nivo primijenjenih bazičnih motoričkih sposobnosti u odnosu na učenike kontrolne grupe.

Rezultati ovog istraživanja pokazuju da je posebni program koji je realizirala eksperimentalna grupa bio obimniji i da je utjecao je na pozitivne transformacije kod gotovo svih motoričkih sposobnosti, a naročito koordinaciju, eksplozivnu snagu, repetitivnu snagu i fleksibilnost. To je bilo i očekivano, jer je program obilovao programskim sadržajima iz: atletike, sportske gimnastike i sportskih igara. To su sportovi kod kojih u njihovoj strukturi dominiraju većinom prethodno navedene motoričke osobine.

Može se zaključiti da model koji je realizirala eksperimentalna grupa, organizirano tjelesno vježbanje kroz nastavu tjelesnog i zdravstvenog odgoja u trajanju od 3 sata sedmično u vremenskom periodu od 7 mjeseci, značajnije aktivira i utječe na pozitivan transfer primijenjenih motoričkih sposobnosti, od modela koji realizirala kontrolna grupa koja je radila po postojećem nastavnom planu i programu od 2 sata sedmično. 
Doziranje, distribucija i kontrola opterećenja predstavlja jedan od značajnih faktora ne samo u pogledu intenzifikacije nastavnog procesa, nego i približavanja procesa tjelesnog vježbanja autentičnim problemima učenika. To iz razloga što pod utjecajem adekvatnih kinezioloških operatora i u primjerenom vremenu i prostoru, što podrazumijeva provođenje određenog doziranja, distribucije i kontrole opterećenja, dolazi do pozitivnih promjena u organizmu. Naime, u organizmu dolazi, uz ostalo, do adaptacijskih promjena, što se pozitivno reflektira i na stvaranje povoljnih adaptacijskih struktura, i na ukupno bolje funkcionalno stanje organizma učenika. Jasno je da će se takvi učenici bolje adaptirati na opterećenja za vrijeme nastave, pa će i ukupni efekti rješenja biti veći.

Motorički razvoj djece mlađe školske dobi od presudnog je značaja za cjelokupni razvoj kasnije tokom životnog vijeka čovjeka. Kako najkvalitetnije utjecati na dijete tog uzrasta, jedan je od najvažnijih pitanja kineziologije kao znanosti o vježbanju. Kvaliteta i potvrđivanje određenog programa usmjeravanja djece u sport, te rad s njima, vrlo je osjetljiv faktor $u$ ostvarenju tog cilja.

Iz svih prethodno navedenih konstatacija i zaključaka, a u cilju intenzifikacije $i$ optimalizacije efekata rada $u$ procesu nastave tjelesnog i zdravstvenog odgoja, potrebno je da se plan i program za osnovne škole promijeni u smislu povećanja sedmičnog broja sati tjelesnog i zdravstvenog odgoja s postojeća 2 sata sedmično, na minimalno 3 sata sedmično, te da se nastava realizuje uz nadzor profesora odnosno nastavnika tjelesnog i zdravstvenog odgoja.

\section{Literatura}

1. Babin, J., R. Katić, L. Vlahović (1999). Utjecaj posebno programirane nastave tjelesne $i$ zdravstvene kulture na motoričke sposobnosti sedmogodišnjih učenica. Zbornik radova Kineziologija za 21. stoljeće, Dubrovnik, str. 115 - 116.

2. Bavčević,T., J. Babin, I. Prskalo (2006). Complex group organizational forms - an optimizing factor physical education instruction. Kinesiology 1/2006, Faculty of kinesiology, Zagreb, str. 28 - 39. 
3. Blažević, S. (1997). Utjecaj različito programiranoga kineziološkoga tretmana na promjene u pokazateljima motoričkih sposobnosti. Zbornik radova, Dubrovnik, str. 24 26.

4. Findak V. (1988). Učenik kao subjekt praćenja i provjeravanja rada u tjelesnoj i zdravstvenoj kulturi. Odgoj i obrazovanje na pragu 21. stoljeća, Pedagoško-književni zbor, Zagreb.

5. Findak, V. (1999).Planiranje, programiranje, provođenje i kontrola procesa vježbanja (Planning, programming, implementation and control of the process of exercise), Kineziologija za 21. stoljeće Zagreb, Fakultet za fizičku kulturu, str. 109 - 113.

6. Hadžikadunić, M. (1998). Uticaj programiranog vježbanja na neke antropometrijske karakteristike motoričke i funkcionalne sposobnosti. Fakultet za fizičku kulturu Univerziteta $\mathrm{u}$ Sarajevu, Homosportikus br.1, Sarajevo, str. 9 - 16.

7. Kurelić, N., K. Momirović, M. Stojanović, J. Šturm, Đ. Radojević, N. Viskić - Štalec. (1975). Struktura i razvoj morfoloških i motoričkih dimenzija omladine. Institut za naučna istraživanja Fakulteta za fizičko vaspitanje, Beograd.

8. Kurelić, N., M. Stojanović, D. Đorđević, G. Bala (1978). Stanje rasta, funkcionalnih i motoričkih sposobnosti omladine SR Srbije i uvođenje sistema praćenja fizičkih sposobnosti. Beograd.

9. Luka M., I. Jukić, S. Šimek (2006). Razlike u morfološkim funkcionalnim i motoričkim pokazateljima treniranosti dviju skupina vrhunskih košarkaša. Homo Sporticus 1/2006, Fakultet sporta i tjelesnog odgoja, Sarajevo, str. 19 - 22.

10. Malina, R.M. (1984). Human growth, maturation and regular physical activity. Boilean R.A., ed. Advances in Pedriatic Spoarts Sciences. Human Kinetics, str. 59 - 83.

11. Mraković, M., R. Katić. (1992). Motoričke karakteristike učenika prvog razreda osnovne škole. Zagreb, Kineziologija vol 1 - 2.

12. Mraković, M., V. Findak, D. Metikoš, B. Neljak (1996). Razvojne karakteristike motoričkih i funkcionalnih sposobnosti učenika i učenica osnovnih i srednjih škola. Međunarodni znanstveni časopis iz područja kineziologije i sporta, Fakultet za fizičku kulturu, br. 2/96, Zagreb. 
13. Rađo, I., B. Wolf (2002). Kvantitativne metode u sportu. Univerzitetski udžbenik, Fakultet za fizičku kulturu, Sarajevo.

14. Stanković, A. (2002). Efekti progamirane nastave tjelesnog i zdravstvenog odgoja na neke antropometrijske karakteristike i motoričke sposobnosti učenica i učenika $\mathrm{V}$ razreda. (Magistarski rad), FFK Sarajevo.

15. Skender, N., S. Kendić, M. Tabaković, N. Dujisić (2002). Utjecaj nekih antropometrijskih parametara na motoričke sposobnosti studentica pedagoškog fakulteta univerziteta $\mathrm{u}$ bihaću. Homo Sporticus, 1/02, Fakultet za fizičku kulturu, Sarajevo, str. 113 - 117.

16. Skender, N. (2004). Transformacioni procesi motoričkih sposobnosti i morfoloških karakteristika pod uticajem sedmomjesečnog tretmana kod učenika 3. i 4. razreda osnovne škole. Doktorska disertacija, Fakultet sporta i tjelesnog odgoja, Sarajevo.

17. Tabaković, M., S. Turković, N. Skender (2005). Diskriminativna analiza nekih bazičnih motoričkih sposobnosti učenika sportske gimnazije i učenika mješovite srednje škole. NTS, 1/2005, Fakultet sporta i tjelesnog odgoja, Sarajevo, str. 309 - 317.

\section{Tabela 1}

Vrijednosti aritmetičkih sredina, standardnih devijacija i T-testa motoričkih sposobnosti kod eksperimentalne i kontrolne grupe $\mathrm{u}$ inicijalnom mjerenju

\begin{tabular}{|c|c|c|c|c|c|c|c|c|c|c|}
\hline Varijable & $\begin{array}{l}\text { Grup } \\
a\end{array}$ & $N$ & Mean & $\begin{array}{l}\text { Std. } \\
\text { Deviatio } \\
n\end{array}$ & \begin{tabular}{|l} 
Std. \\
Error \\
Mean
\end{tabular} & $F$ & $d f$ & \begin{tabular}{|l|} 
Sig. \\
$(2-$ \\
tailed)
\end{tabular} & $\begin{array}{l}\text { Mean } \\
\text { Diff }\end{array}$ & $\begin{array}{l}\text { Std. } \\
\text { Err } \\
\text { Dif }\end{array}$ \\
\hline \multirow{2}{*}{ MKOPZD } & 1.00 & 102 & 13.13 & 2.03 & .20 & 3.74 & 204 & .00 & .91 & .24 \\
\hline & 2.00 & 104 & 12.22 & 1.51 & .14 & & 186.90 & .00 & .91 & .25 \\
\hline \multirow{2}{*}{ MKOSDN } & 1.00 & 102 & 58.97 & 11.03 & 1.09 & 2.87 & 204 & .18 & 1.92 & 1.43 \\
\hline & 2.00 & 104 & 57.04 & 9.51 & .93 & & 198.52 & 2.18 & 1.92 & 1.43 \\
\hline \multirow{2}{*}{ MKOKS } & 1.00 & 102 & 13.28 & 1.36 & .13 & 30 & 204 & .44 & -.15 & .19 \\
\hline & 2.00 & 104 & 13.43 & 1.50 & .14 & & 202.85 & 5.44 & -.15 & .19 \\
\hline \multirow{2}{*}{ MKOT10X5 } & 1.00 & 102 & 21.55 & 1.81 & .17 & .009 & 204 & .81 & & .25 \\
\hline & 2.00 & 104 & 21.49 & 1.84 & .18 & & 203.99 & .81 & & .25 \\
\hline MESSDM & 1.00 & 102 & $\begin{array}{l}133.2 \\
9\end{array}$ & 14.05 & 1.39 & .69 & 204 & .14 & 3.03 & 2.09 \\
\hline
\end{tabular}




\begin{tabular}{|c|c|c|c|c|c|c|c|c|c|}
\hline & 2.00 & $104 \mid \begin{array}{l}130.2 \\
5\end{array}$ & 15.91 & 1.56 & & 201.80 & & 3.03 & 2.09 \\
\hline \multirow{2}{*}{ MESSAR } & 1.00 & 10222.77 & 4.16 & .41 & .05 & 204 & .59 & .31 & .58 \\
\hline & 2.00 & 10422.46 & 4.17 & .40 & & 203.93 & .59 & .31 & .58 \\
\hline \multirow{2}{*}{ MEST20M } & 1.00 & 1024.40 & .36 & & .96 & 204 & .33 & & \\
\hline & 2.00 & 1044.35 & .41 & & & 201.18 & .33 & & \\
\hline \multirow[b]{2}{*}{ MRSPTT } & 1.00 & 10220.99 & 6.50 & .64 & 4.26 & 204 & .70 & -.31 & .82 \\
\hline & 2.00 & \begin{tabular}{|l|l|}
104 & 21.30 \\
\end{tabular} & 5.27 & .51 & & 194.16 & .70 & -.31 & .82 \\
\hline \multirow{2}{*}{ MRSDC } & 1.00 & 10234.15 & 5.87 & .58 & 5.38 & 204 & .70 & .29 & .75 \\
\hline & 2.00 & \begin{tabular}{|l|l|}
1043.86 \\
\end{tabular} & 4.97 & .48 & & 197.32 & .70 & .29 & .75 \\
\hline \multirow{2}{*}{ MRSIZZ } & 1.00 & \begin{tabular}{|l|l|}
102 & 18.53 \\
\end{tabular} & 13.77 & 1.36 & .34 & 204 & .10 & 2.98 & 1.83 \\
\hline & 2.00 & \begin{tabular}{|l|l|}
104 & 15.54 \\
\end{tabular} & 12.48 & 1.22 & & 201.21 & .10 & 2.98 & 1.83 \\
\hline \multirow{2}{*}{ MBTR } & 1.00 & \begin{tabular}{|l|l|l|}
1022.79 \\
\end{tabular} & 2.75 & .27 & 2.84 & 204 & .02 & .96 & .42 \\
\hline & 2.00 & \begin{tabular}{|l|l|}
104 & 21.82 \\
\end{tabular} & 3.32 & .32 & & 198.43 & .02 & .96 & .42 \\
\hline \multirow{2}{*}{ MBTN } & 1.00 & \begin{tabular}{l|l|l|}
102 & 16.69 \\
\end{tabular} & 2.48 & .24 & 1.94 & 204 & .44 & .24 & .31 \\
\hline & 2.00 & \begin{tabular}{l|l|l|l|}
104 & 16.45 \\
\end{tabular} & 2.06 & .20 & & 195.86 & .44 & .24 & .31 \\
\hline \multirow{2}{*}{ MBTNZ } & 1.00 & \begin{tabular}{l|l|l|l|l|}
102 & 14.43 \\
\end{tabular} & 3.09 & .30 & 1.75 & 204 & .07 & .82 & .46 \\
\hline & 2.00 & \begin{tabular}{|l|l|}
13.60 \\
\end{tabular} & 3.50 & .34 & & 201.80 & .07 & .82 & .46 \\
\hline \multirow{2}{*}{ MFDP } & 1.00 & 1024.06 & 5.18 & .51 & .02 & 204 & .42 & .57 & .71 \\
\hline & 2.00 & 1043.49 & 5.07 & .49 & & 203.66 & .42 & .57 & .71 \\
\hline \multirow[b]{2}{*}{ MFIP } & 1.00 & \begin{tabular}{|l|l|}
102 & 68.08 \\
\end{tabular} & 13.66 & 1.35 & .14 & 204 & .43 & 1.54 & 1.95 \\
\hline & 2.00 & \begin{tabular}{|l|l|}
104 & 66.54 \\
\end{tabular} & 14.43 & 1.41 & & 203.74 & .43 & 1.54 & 1.95 \\
\hline \multirow{2}{*}{ MFPSR } & 1.00 & \begin{tabular}{|l|l|l|}
102 & 85.88 \\
\end{tabular} & 10.11 & 1.00 & 13 & 204 & .93 & -.10 & 1.38 \\
\hline & 2.00 & \begin{tabular}{|l|l|}
105.99
\end{tabular} & .81 & .96 & & 203. & .93 & -.10 & $1 .$. \\
\hline
\end{tabular}

\section{Tabela 2}

Vrijednosti aritmetičkih sredina, standardnih devijacija i T-testa motoričkih sposobnosti kod eksperimentalne i kontrolne grupe $u$ finalnom mjerenju

\begin{tabular}{|c|c|c|c|c|c|c|c|c|c|c|}
\hline Varijable & Grupa & $N$ & Mean & $\begin{array}{l}\text { Std. } \\
\text { Deviatio } \\
n\end{array}$ & $\begin{array}{l}\text { Std. } \\
\text { Error } \\
\text { Mean }\end{array}$ & $F$ & $d f$ & $\begin{array}{l}\text { Sig. } \\
(2- \\
\text { tailed) }\end{array}$ & $\begin{array}{l}\text { Mean } \\
\text { Diff }\end{array}$ & $\begin{array}{l}\text { Std. } \\
\text { Err } \\
\text { Dif }\end{array}$ \\
\hline \multirow{2}{*}{ MKOPZD } & 1.00 & 102 & 16.39 & 2.19 & .21 & 65 & 204 & .00 & 1.68 & .29 \\
\hline & 2.00 & 104 & 14.71 & 2.04 & .20 & & 202.39 & .00 & 1.68 & .29 \\
\hline \multirow{2}{*}{$\begin{array}{l}\text { MKOSD } \\
\mathrm{N}\end{array}$} & 1.00 & 102 & 64.12 & 11.93 & 1.18 & .02 & 204 & .33 & 1.63 & 1.68 \\
\hline & 2.00 & 104 & 62.49 & 12.28 & 1.20 & & 203.98 & .33 & 1.63 & 1.68 \\
\hline \multirow{2}{*}{ MKOKS } & 1.00 & 102 & 11.09 & .87 & & 13.97 & 204 & .00 & -.80 & .14 \\
\hline & 2.00 & 104 & 11.89 & 1.16 & .11 & & 191.33 & .00 & -.80 & .14 \\
\hline \multirow{4}{*}{$\begin{array}{l}\text { MKOT10 } \\
\text { X5 }\end{array}$} & 1.00 & 102 & 19.94 & 1.46 & .14 & 5.91 & 204 & .00 & -1.15 & .22 \\
\hline & 2.00 & 104 & 21.10 & 1.76 & .17 & & 198.56 & .00 & -1.15 & .22 \\
\hline & 1.00 & 102 & 138.22 & 15.40 & 1.52 & .74 & 204 & .02 & 5.14 & 2.24 \\
\hline & 2.00 & 104 & 133.07 & 16.75 & 1.64 & & 203.16 & .02 & 5.14 & 2.24 \\
\hline
\end{tabular}




\begin{tabular}{|c|c|c|c|c|c|c|c|c|c|}
\hline \multirow{2}{*}{ MESSAR } & 1.00 & \begin{tabular}{l|l|}
102 & 27.56 \\
\end{tabular} & 3.93 & .39 & 1.09 & 204 & .00 & 2.469 & .57 \\
\hline & 2.00 & 10425.10 & 4.29 & .42 & & 203.10 & .00 & 2.46 & .57 \\
\hline \multirow{2}{*}{\begin{tabular}{|l} 
MEST20 \\
M
\end{tabular}} & 1.00 & 1024.01 & .24 & & 4.83 & 204 & .00 & -.23 & \\
\hline & 2.00 & 1044.25 & .28 & & & 199.18 & .00 & -.23 & \\
\hline \multirow{2}{*}{ MRSPTT } & 1.00 & 10228.39 & 5.52 & .54 & .68 & 204 & .00 & 4.70 & .73 \\
\hline & 2.00 & \begin{tabular}{|l|l|}
104 & 23.68 \\
\end{tabular} & 4.94 & .48 & & 200.63 & .00 & 4.70 & .73 \\
\hline \multirow{2}{*}{ MRSDC } & 1.00 & 10237.09 & 5.60 & .55 & 4.13 & 204 & .00 & 2.18 & .70 \\
\hline & 2.00 & 10434.91 & 4.47 & .43 & & 192.92 & .00 & 2.18 & .70 \\
\hline \multirow{2}{*}{ MRSIZZ } & 1.00 & \begin{tabular}{|l|l|}
10234.12 \\
\end{tabular} & 26.56 & 2.63 & 13.47 & 204 & .00 & 13.78 & 3.02 \\
\hline & 2.00 & \begin{tabular}{|l|l|}
104 & 20.34 \\
\end{tabular} & 15.60 & 1.53 & & 162.66 & .00 & 13.78 & 3.04 \\
\hline \multirow{2}{*}{ MBTR } & 1.00 & 10224.97 & 3.02 & .29 & 1.31 & 204 & .00 & 1.21 & .43 \\
\hline & 2.00 & 10423.75 & 3.16 & .31 & & 203.85 & .00 & 1.21 & .43 \\
\hline \multirow{2}{*}{ MBTN } & 1.00 & \begin{tabular}{l|l|l|l|}
102 & 18.68
\end{tabular} & 1.75 & .17 & 3.68 & 204 & .00 & .85 & .26 \\
\hline & 2.00 & \begin{tabular}{|l|l|}
104.82 \\
\end{tabular} & 2.07 & .20 & & 199.81 & .00 & .85 & .26 \\
\hline \multirow{2}{*}{ MBTNZ } & 1.00 & \begin{tabular}{|l|l|}
102 & 16.10 \\
\end{tabular} & 2.46 & .24 & 2.11 & 204 & .02 & .81 & .36 \\
\hline & 2.00 & \begin{tabular}{|l|l|}
104 & 15.28 \\
\end{tabular} & 2.71 & .26 & & 202.81 & .02 & .81 & .36 \\
\hline \multirow{2}{*}{ MFDP } & 1.00 & 1027.56 & 4.73 & .46 & 1.26 & 204 & .00 & 2.70 & .63 \\
\hline & 2.00 & 1044.86 & 4.38 & .42 & & 202.05 & .00 & 2.70 & .63 \\
\hline \multirow{2}{*}{ MFIP } & 1.00 & 10261.20 & 11.90 & 1.17 & .54 & 204 & .00 & -5.68 & 1.72 \\
\hline & 2.00 & 10466.89 & 12.84 & 1.25 & & 203.34 & .00 & -5.68 & 1.72 \\
\hline \multirow{2}{*}{ MFPSR } & 1.00 & 10292.99 & 10.10 & 1.00 & .27 & 204 & .00 & 4.16 & 1.36 \\
\hline & 2.00 & 10488.82 & 9.42 & .92 & & 202.40 & .00 & 4.16 & 1.36 \\
\hline
\end{tabular}

Tabela 3 Box's M test

Diskriminativna analiza efekata programa kod eksperimentalne i kontrolne grupe ispitanika

\begin{tabular}{|l|l|}
\hline Box's $M$ & 224,17 \\
\hline F Approx. & 1,51 \\
\hline df1 & 136 \\
\hline df2 & 128415,02 \\
\hline Sig. & $\mathbf{0 0}$ \\
\hline
\end{tabular}

\section{Tabela 4}

Značajnost izoliranih diskriminativnih funkcija

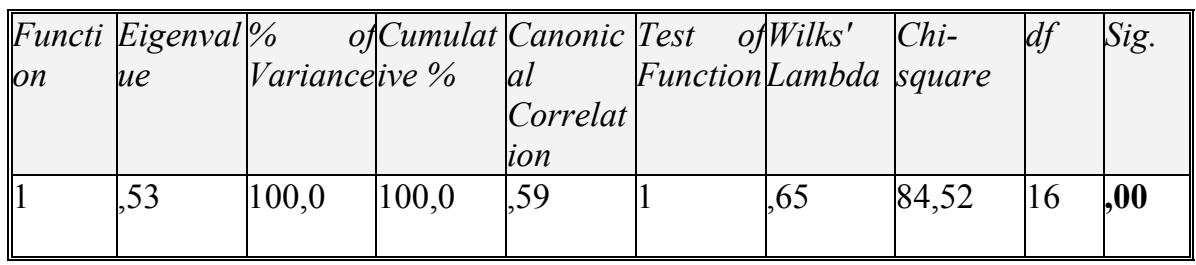


Tabela 5

Struktura diskriminativne funkcije i centroidi grupa

\begin{tabular}{|c|c|}
\hline Varijable & $\begin{array}{l}\text { Function } \\
1\end{array}$ \\
\hline MEST20M &, 61 \\
\hline MRSPTT &,- 61 \\
\hline MKOPZD &,- 54 \\
\hline MKOKS &, 53 \\
\hline MKOT10X5 & 48 \\
\hline MRSIZZ &,- 43 \\
\hline MESSAR &,- 40 \\
\hline MFDP &,- 40 \\
\hline MFIP &, 31 \\
\hline MBTN &,- 30 \\
\hline MRSDC &,- 29 \\
\hline MFPSR &,- 29 \\
\hline MBTR &,- 26 \\
\hline MESSDM &,- 21 \\
\hline MBTNZ &,- 21 \\
\hline MKOSDN &,- 09 \\
\hline Group 1 &,- 738 \\
\hline Group 2 &, 724 \\
\hline
\end{tabular}


DR, NIJAZ SKENDER, P.H.D.

\section{ANALYSIS OF DIFFERENCES IN MOTORIC ABILITIES OF PUPILS IN THIRD AND FOURTH GRADES OF PRIMARY SCHOOLS UNDER THE INFLUENCE OF SPECIAL KINEOLOGICAL PROGRAM}

\section{SUMMARY}

For the purposes of establishing the quantitive differences of movable capabilities, there was a research performed on the sample of 206 examinees(students of primary school-3rd and 4th grade).All the examiners were students of the primary school ,25th November" from Velika Kladuša.During the research,the assemblage of 16 variables of movable capabilities was used.

The aim of this study is to research transformation of motoric abilities of pupils by using the parallel analysis. The parallel analysis of the result of the experimental and control group of pupils has the the aim to show which model of curriculum has better results in the transformation of motoric abilities.

Analising the partial quantitive changes(tested with T-test)of movable capabilities of experimental and control group in initial measuring, it was realised that there were no important partial differences for many movable variables between experimental and control group.Taking that into consideration,it was concluded that those two groups of examinees belong to the same population.

Taking into consideration the parametres of tested movable capabilities (tested with T-test) of experimental and control group in final measuring, it was realised that there were two important partial differences in all variables of motorical capabilities (except one) between experimental and control group.

Taking into consideration the results of the discriminative analysis as well as the global differences of applied movable variables between experimental and control group after these two parallel programmes were completed, it was realised that between these two groups were important global differences in tests of movable capabilities influenced by two different programmes. The experimental 
group program initiated the positive transformations of almost all motoric abilities, especisll motoric abilities, especially in coordination, explosive pwer, repetitive strenght and flexibility. 
د. نياز سكندر

\section{تحليل فروق إمكانيات التحرك لدى تلاميذ الصف الثالث والرابع الابتدائي}

\section{تحت تأثير برنامج التحرك الحخاص لياص}

\section{خلاصة البحث}

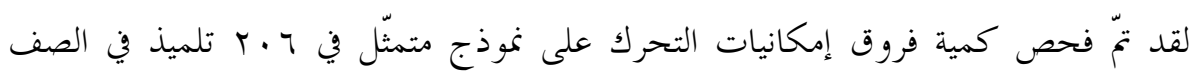

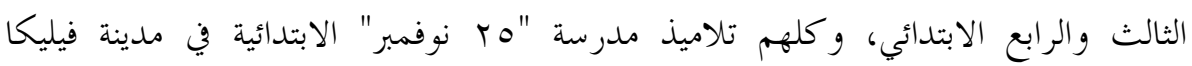

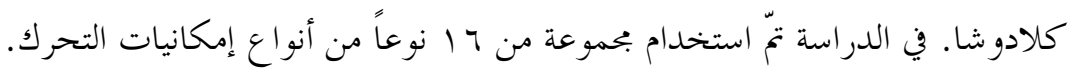

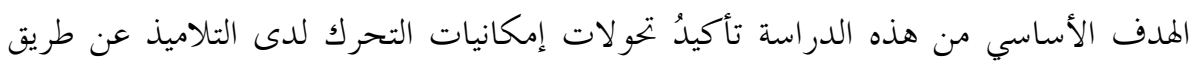

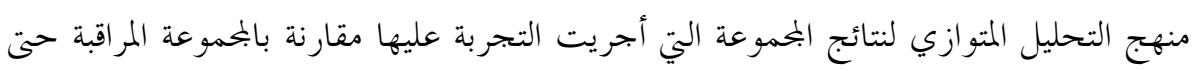

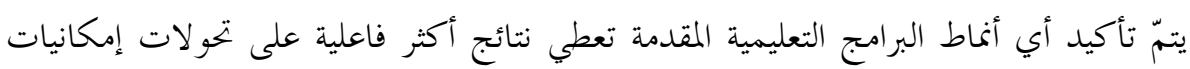
التحرك.

من خلال تحليل التغيّرات الكمية الجزئية التي أجري عليها (عن طريق فحص T) فحص

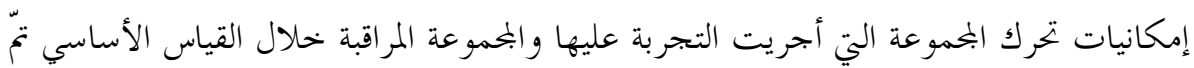

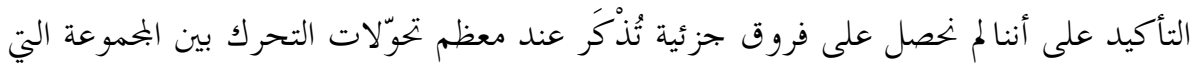

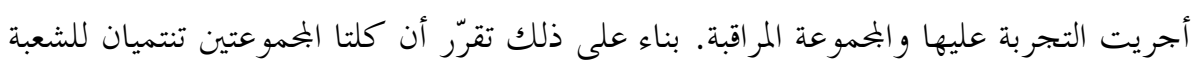

نفسها.

على أساس المعايير المتحصل عليها (عن طريق فحص T) من فحص إمكانيات تحرك المجموعة

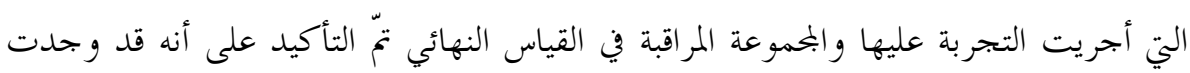
فروق جزئية ملحوظة في جميع أنواع إمكانيات تحرك (ما عدا واحدة) بين المحموعة التي أجريت التجربة عليها و البحموعة المراقبة.

بناء على نتائج التحليل التفريقي بين الفروق العامة المطبّقة على أنواع تحرك بين المحموعة التي

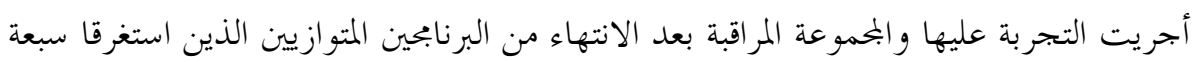

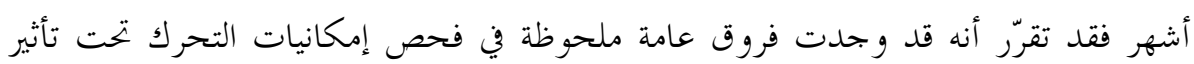
فعالية برنابحين مختلفين. 
إن برنامج المحموعة التي أجريت عليها التجربة والذي كان ضخماً قد أثّر على التحوّلات

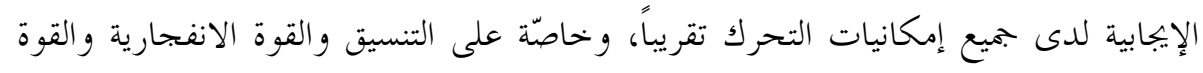
التكرارية و المرونة. 